\title{
Melanoma of the Ciliary Body and Choroid pT1a TNM Finding v7
}

National Cancer Institute

\section{Source}

National Cancer Institute. Melanoma of the Ciliary Body and Choroid pT 1a TNM Finding v7. NCI Thesaurus. Code C88687.

Tumor size category 1 without ciliary body involvement and extraocular extension. (from AJCC 7th Ed.) 